\title{
Endocrine and Autonomic Nervous Adaptations during Physical Exercise in Down Syndrome
}

\author{
Véronique Aurélie Bricout \\ CHU Sud de Grenoble, UF Recherches Cliniques, Université Joseph Fourier UFRAPS, \\ Laboratoire HP2, Grenoble
}

France

\section{Introduction}

One of the goals of Healthy People 2011 is to increase the quality of life and the years of healthy life of all citizens. As the life expectancy of people with Down Syndrome [DS] increases, changes in body function and structure due to ageing may lead to lead to activity limitations and participation restrictions for this population. The physical conditions seen in people with DS include endocrine dysfunction, cardiovascular disorders, obesity, and musculoskeletal disorders (Finesilver, 2002; Thompson, 1999). These physical problems can have a negative impact on the quality of life, regarding both professional and leisure activities.

Compared with their peers who are not mentally retarded, individuals with DS, regardless of their age, have lower cardiovascular fitness levels (Horvat \& Croce, 1995; Tsimaras et al., 2003). This lower level of cardiovascular fitness may be the result of poor eating habits, a sedentary lifestyle, a lack of opportunity for recreational activities, a poor coordination, and a poor motivation for physical activity. In addition, the lack of cardiovascular fitness may be due to or caused by the high obesity rates observed among adults with mental retardation (Draheim et al., 2002). Poor cardiovascular fitness levels also may contribute to an increased risk of heart disease and stroke in adults with mental retardation (Sutherland et al., 2002).

Therefore, involvement in cardiovascular conditioning programs would seem to be essential, however, can the cardiovascular fitness levels of these individuals, be improved with exercise, without major health risks?

If exercise programs seem to be likely to improve the health of adults with DS, thereby increasing their quality of life and life expectancy, yet further research is needed to investigate the effects of exercise on adults, because some autonomic nervous regulations and endocrine adaptations are known to be inadequate in individuals with DS (Baynard et al., 2004; Figueroa et al., 2005; Iellamo et al., 2005; Gouloupoulou et al., 2006; Bricout et al. 2008).

\section{Situation of the subject in international literature}

One hypothesis explaining the improvements in life expectancy of DS individuals is based on the physical stimulation and psychological standing of these subjects (Eberhard et al., 1989; Draheim et al., 2002). Now, adults with trisomy 21 are living longer than previously 
and individuals surviving into their sixth or seventh decade of life are encountered (Prasher \& Krishnan, 1993). So, there is a need for an overall assessment of the health of adults with trisomy 21, and specifically as the sport activities helps improve the quality of life, and reduce risk factors, it seems important to know the possible effects of physical exercise on the health of these young people with Down syndrome.

In this order, few studies have investigated cardiac and hormonal responses in patients with Down syndrome subjected to acute physical exercise (Murdoch, 1977; Murdoch et al. 1978; Fernhall \& Otterstetter, 2003; Baynard et al., 2004; Iellamo et al., 2005; Figueroa et al., 2005; Gouloupoulou et al., 2006). The conclusions of these few studies show that there are inappropriate responses that lead to the appearance of early fatigue, a premature stop of the effort, and/or a limitation to the activity. It was previously suggested that fatigue during exercise, or at least premature stop or the incapacity to do prolonged physical exercise in DS subjects, may partly be explained by a dysfunction of the autonomic nervous system [ANS] (Baynard et al., 2004; Iellamo et al., 2005; Figueroa et al., 2005; Gouloupoulou et al., 2006).

Secondly, others studies have investigated the hormonal adaptation's in specific physical tests and the results of all these works agree to show that heart rate [HR] is lower $(-7$ to 15 beats per minute) in DS individuals. Specifically, numerous studies hypothesized that the lower catecholamine responses (epinephrine and norepinephrine) in DS population to maximal exercise could explain the weaker heart rate (Fernhall et al., 2009).

These observations are reinforced by the results of a work achieved by Eberhard et al., (1989, 1991) and Bricout et al., (2008) evaluating catecholamine's kinetics during and after exercise. These authors showed that the plasma concentrations of epinephrine and norepinephrine after an exercise on bicycle or on treadmill were lower in subjects with DS than in control subjects, and could partly explain the relatively low elevation of HR during exercise, named "chronotropic incompetence".

However, some others factors may explain the reduced aerobic capacity and the possible incapacity to long physical exercise in DS. If endocrine dysfunction, cardiovascular pathologies, obesity, and musculoskeletal disorders are now well established as limiting to do prolonged physical exercise, DS individuals were also not highly motivating to repeat exercise, which contributes to more easily adopt a sedentary lifestyle, because the effort can be quickly perceived as painful, difficult and without sense for them.

The mechanisms of exercise intolerance in trisomy 21 require further consideration and in particular the relationship between the sympathetic nervous system, hormonal system which its importance in the adaptation effort is crucial.

Thus, many studies confirm that DS subjects present some endocrine diseases, such as diabetes, hypothyroidism, and insulin resistance ... (Murdoch, 1977; Murdoch et al. 1978; Sharav et al., 1991; Sasagawa et al., 1993; Konings et al., 2001). In a study conducted at the University Hospital of Grenoble between 2003 and 2005, on 14 young adults with trisomy 21, some of these endocrine disorders at rest (hypothyroidism and hypogonadism) were confirmed.

During muscular effort, it was shown that the responses of the adrenal axis (cortisol and catecholamine) and gonadal axis (testosterone) especially are the most affected when exercise is prolonged. Indeed, with exercise, the elevated catecholamine response, classically described in healthy subjects (Galbo, 1985) is lower in DS patients, and it can be suggested that the decreased response of catecholamine during effort in DS subjects explains the lesser capacity of these subjects to perform a muscular exercise which intensity and duration rise (Nagaoka et al., 1996; Fernhall \& Otterstetter, 2003,). 
In addition, some studies show that in patients with Down syndrome without adrenal insufficiency, basal cortisol is always lower (Murdoch, 1977; Murdoch et al. 1978). The pathogenesis of this observation remains difficult to explain, although it may have metabolic and physiological implications. During muscular exercise, the elevation of plasma cortisol, classically described in healthy subjects does not occur in DS subjects (Eberhard et al., 1993; 1996). Several hypotheses may be advanced to explain this fact:

- insufficient effort in intensity and / or duration, for subjects with trisomy are very reluctant to make long efforts,

- a possible adrenal dysfunction, which yet, remains unlikely (Konings et al., 2001). A more general dysfunction of the hypothalamic-pituitary-adrenal could exist, but the lack of studies on the regulation of secretion of CRF and ACTH in Down syndrome does not allow us to reverse or confirm this hypothesis. If dys-regulation of the HPA axis to stress in DS individuals partly explains the difficulty to use free fatty acids as energy substrates, there may be other endocrine factors directly related to adipose tissue, such as leptin, or in connection with the gonadotropic through testosterone, and its lipolytic action (Galbo, 1985).

Moreover, Bricout et al., (2008) show that DS subjects are characterised by an absence of elevated glycaemia during prolonged exercise, contrary to what is observed in healthy controls (Galbo, 1985). In addition, the concentration of lactatemia rises less than in controls suggesting that the peripheral utilisation of glucose is impaired. Therefore, it seems highly relevant to examine whether the gluco-regulation during exercise is impaired by a dysfunction of the autonomic nervous system response and / or impaired secretion of catecholamines and / or balance insulin / glucagon imbalance; and to know its impact on exercise capacity.

Furthermore, results of maximal exercise test show that 4 in 14 subjects presented chronotropic incompetence, and that these patients have an altered metabolic profile (increased fat mass, alterations in leptin, insulin, cortisol and plasma catecholamine at rest and during exercise) suggesting the close link between chronotropic incompetence, abnormal metabolic profile and endocrine regulation. These points deserve to be confirmed by future studies.

Recently, Fernhall et al., (2009) have conducted a study on catecholamine response to maximal exercise in persons with Down syndrome. This work reported an adrenergic drive largely absent in DS group, even though a sharp increase in catecholamine at high exercise intensities is largely responsible for increase in HR above the anaerobic threshold. In conclusion, the authors showed significant differences in baroreceptor sensitivity between individuals with and without DS, but not between DS compared with controls, suggesting that altered baroreceptor sensitivity does not fully explain the blunted HR response in DS population.

\section{Exercise limitations and chronotropic incompetence}

Meanwhile, investigation methods of the sympathetic nervous system are now well known and described in literature to be applied in this context (Nagaoka et al., 1996; Grote et al., 2004; Gouloupoulou et al., 2006). The measurement of heart rate variability is a non invasive method to assess both parasympathetic and sympathetic nervous activities (Task Force, 1996). The application of this method has revealed abnormalities associated with abnormal fatigue in athletes (Furlan et al., 1993). It has recently been used in trisomy 21 at rest, 
exercise and orthostatic tests (Baynard et al., 2004; Fernhall et al., 2005; Iellamo et al., 2005; Figueroa et al., 2005).

The common hypothesis found in literature is that the individual with Down syndrome, has a reduced exercise capacity associated with chronotropic incompetence, expressed by maximum heart rate values (HRmax) decreased in response to a standardised exercise (Fernhall et al., 2001). Because peak exercise HR is correlated with age, the traditional approach has been to consider a patient as chronotropically incompetent when $85 \%$ of the age-predicted HR is achieved (Lauer, 2004). This measure is still confounded (Lauer et al., 1996) by resting HR and functional capacity, and Wilkoff \& Miller, (1992) proposed the concept of HR reserve which is the difference between maximal predicted HR (or 220 beats / min minus the patient's age) and resting HR. Failure to use $80 \%$ of HR reserve constitutes chronotropic incompetence (Lauer et al., 1996).

In DS population, reduced HR response to prolonged exercise has been identified as the primary contributor to the low physical work capacity and cardiorespiratory fitness (Fernhall et al., 1996; 2001), but chronotropic incompetence is also an independent predictive factor of sudden death even in adult DS population without underlying coronary heart disease. Although it is debated (Guerra et al., 2003); understand the chronotropic incompetence in DS may be clinically relevant because it could partially explain the higher incidence of premature cardiac death in this population (Day et al., 2005).

Nevertheless, the mechanism of this alteration of cardiac response remains unknown, although dysregulation of the ANS appears to be the most probable explanation, by a decrease in sympathetic stimulation during exercise, and vagal tone incompletely removed (Fernhall et al., 2000; 2001). The rise in heart rate, normally induced by the removal of vagal inhibition and a gradual increase in sympathetic activation, is lower in DS population during a muscular effort (Fernhall \& Otterstetter, 2003). This autonomic dysfunction has been studied by Figueroa et al. (2005) who used the HR variability [HRV] to explore the autonomic modulation of the sinoatrial node at rest and during exercise. Spectral components of HRV analysis in the low frequency [LF] and high frequency [HF] bands reflect sympathetic activity [LF/HF ratio] and parasympathetic tone [HF spectrum] (Task Force, 1996). These authors report an attenuated HR in individuals with DS due to blunted vagal withdrawal.

The results of these studies show significant abnormalities of ANS, with an observed increase in parasympathetic tone at rest (Baynard et al., 2004) a decrease of sympathetic stimulation during stress and during the tilt test, evoke a possible recall impaired baroreflex (Fernhall et al., 2005).

So, the mechanism responsible for the impairment of the autonomic cardiac regulation in DS population remains unclear. Even if the dysfunction of the ANS and /or the hormonal system is the main areas of research, we can also suggest that neurological damage are involved in the impairment of this cardiac regulation. The consistent findings of abnormalities in brain stem auditory evoked potentials, failure of growth and maturation in the brain from an early age, with loss of neurons and dentrites, and damage to the neurotransmitter system would provide the anatomic substrate for the autonomic dysfunction occurring at a central, brain stem site as a result of the genetic disorder (Yates et al., 1980; Mann et al., 1985; Wisniewski, 1990).

In the future, this dysfunction of the ANS must be supplemented by further investigations to better understand the possible mechanisms, especially through the involvement of hormonal factors. 


\section{Exercise limitations and obesity}

One of the characteristics of the person with trisomy 21 is the propensity for becoming obese (Murray \& Ryan-Krause, 2010). It affects between 15 and 20\% of children and develops in most cases early in age; some studies have shown that nearly $10 \%$ of the children with Down syndrome were already located beyond the $95^{\circ}$ percentile at 4 years old (Beange et al., 1995). The development of physical activity in the management of the obesity of young Down syndrome could play a major role. Indeed, the benefits of physical activity (combined with dietary measures) on cardiovascular risk have been clearly demonstrated in these populations, whether they live in special centers or in a family environment (Draheim et al., 2002; Montgomery et al., 1988).

Thus, in the general population, as in that of Down's syndrome, cardiovascular risk factors are associated with metabolic abnormalities, which are grouped under the generic common name 'metabolic syndrome' (Grundy et al., 2000). Among these metabolic abnormalities we can note a decrease in insulin resistance and excess body fat. Being overweight or obese can increase insulin resistance, which is characterised by a lack of insulin to stimulate glucose uptake by peripheral tissues and muscles, even though the plasma insulin concentration is abnormally high. The numerous endocrine studies showed that hyper-insulinemia stimulates the sympathetic nervous system, as is found in obese subjects (Monroe et al., 2000). This activation of the sympathetic nervous system is paradoxical, because it is part of a vicious circle in which there is a desensitisation of adrenergic signalling pathways (Lohse, 1996) hence a decrease in energy expenditure easing body fat storage. Simultaneously, this activation of the sympathetic nervous system adrenergic effects on the heart, blood vessels and kidneys promotes the development of hypertension. All these factors contribute highly to rise cardiovascular risk factors.

However, the factors restricting the effort in obesity are still insufficiently explored, especially for subjects with a mental disability. It seems that the place of regular physical activity in this population is highly relevant, especially since many studies have shown smaller performance in trisomy 21 (Pitetti \& Tan, 1991a; Pitetti \& Campbell, 1991b; Guerra et al., 2003; Fernhall \& Otterstetter, 2003). The reasons for this disability to exercise are not clear and may reflect an insufficient stimulation (motivation problem) and / or the onset of fatigue induced by a limitation of use of energy substrates during prolonged exercise (Bricout et al., 2008) or to increased oxidative stress (Flore et al., 2008).

In adults, excess body fat may induce inflammation called 'low grade' and excessive oxidative stress (Wellen \& Miller, 2005). Adipose tissue, then produce pro-inflammatory cytokines that alter insulin sensitivity. On the other hand, an inverse relationship between fitness level and markers of inflammation (high-sensitivity CRP) suggest a protective role of physical activity. Thus, the decrease in circulating CRP in regular physical activity suggests that it may limit this low-grade systemic inflammation (Oberbach et al., 2006). The effects of acute exercise have also been clearly demonstrated on the action of TNF- $\alpha$ (suppressive effect). Thus in young Down syndrome often over-weight and with a high percentage of body fat, the study of low-grade inflammation, its relationship with insulin sensitivity, biological markers of metabolic risk and cardiovascular inactivity and fitness need to be clarified. Several authors have demonstrated the positive impact of endurance exercise training on these markers. This reduced level of sensitivity CRP could reach $40 \%$ and was distinct from body composition and the level of initial CRP (Colbert et al., 2004). The checking of such a systemic effect in favour of a specific population "at risk" is therefore 
highly pertinent. This reduction in plasma levels of inflammatory markers may represent a relevant therapeutic target.

\section{Hormonal results during physical exercise in people with Down syndrome and possible link with an exercise limitation?}

Historically, people with intellectual disabilities have long been away from sports associations. Then gradually, with the development of adapted physical activities, awareness of the benefits of such control on health has raised, and attitudes to integrate these people have evolved (Eberhard, 2006). The first work that reports on the involvement of subjects with mental disabilities in sport is those of Bell and colleagues in 1977, demonstrating the feasibility of integrating these people into sport. In the following decade, many studies will have demonstrated that training and regular codified sports practices are not only possible but present real health benefits (Pitetti et al., 1989; 1991a; 1991b; 1993; Draheim et al., 2002). In this analysis, we must differentiate the effects of practice on health indicators (e.g. on body fat, the risk of obesity ...) from indicators of performance, not specifically looked for in this context.

Thus, for subjects with trisomy 21, regular physical activity can for example:

- promote fat loss, and positively influence lipid parameters (cholesterol, lipoproteins; (Eberhard et al., 1993))

- $\quad$ reduce the risk of developing diabetes (Marliss \& Vranic, 2002; McGavock et al., 2004)

- $\quad$ reduce the risk of developing hypertension (Fernhall et al., 2001)

- $\quad$ help perform long-term efforts.

For twenty years, the department of Sports Medicine, at the hospital of Grenoble, has been focusing on hormonal adaptations during exercise in young trisomy 21. Early works attached in 1989 (Eberhard et al., 1989) tested the effects of a short physical exercise on a cycle ergometer to evaluate the physical abilities of young DS teenagers. These preliminary results showed that DS subjects had a less important physical ability to make efforts not only because of a lack of motivation or behavioural problems, but also a possible cardiovascular dysfunction. Two years later the major result led, to propose further investigations on the relationship between "the biochemical adaptations and catecholamine responses after a maximum incremental exercise in these young DS teenagers (Eberhard, et al., 1991). This study has highlighted that exercise performed by young DS individuals is reflected by elevated plasma catecholamine lower than that traditionally seen in control subjects, also correlated with a maximum heart rate always lower than control subjects at the end of exercise. The hypothesis of a blunted adrenergic response in this population therefore emerged. In 1993, a new study was proposed in the department with the aim to assess metabolic parameters at rest then an effort, but also and after 12 weeks of training, the idea was to make the possible link with adaptive responses to exercise (Eberhard, et al., 1993, 1996, 1997). The results obtained in these studies confirmed the previous ones results, but also demonstrated that endurance training over a period of three months led to a better balance of lipid profile frequently observed to be abnormal in a sedentary population with Down syndrome.

This promotion of physical activity has becomes a real concern for this specific population. Relayed by local associations, it has given rise to a major support of young Down syndrome, involving them more in physical activities. Over the last years, adaptive sports clubs which include a large population of mentally handicapped people, have regularly organized 
weekly training sessions that allow these young people to compete at a national level, and some of them achieve excellent results. These benefits had an immediate impact, improving measurable physiological parameters during exercise testing.

For example, in a last study proposed in 2002 in France (Grenoble), $\mathrm{VO}_{2 \max }$ values (gold index of aerobic fitness) obtained by a group of young DS adults, are excellent (44.2 \pm 3.0 $\mathrm{ml} \cdot \mathrm{min}^{-1} \cdot \mathrm{kg}^{-1}-\mathrm{Min}=39$ Max $=60$ ). For higher values, some young DS subjects get even better results than some control subjects of similar age. However, in this work, hormonal and metabolic investigations have shown that DS subjects present some alterations in adaptive response to maximal and sub-maximal exercise. Specific factors appear to be associated with result, such as obesity, a high percentage of body fat, hyper-insulinemia, and hyper-leptin levels (Bjorntrop \& Rosmond, 2000). During the sub-maximal exercise, hormonal responses of young DS adults (cortisol, catecholamine) do not follow the observed rise in controls, whereas these adaptations allow glycolysis, gluconeogenesis and lipolysis when muscular exercise continues.

This result is expressed in a moderate elevation of blood glucose and HR, which could explain why people with Down syndrome can not continue muscular effort even at levels below maximum (Bjorntrop \& Rosmond, 2000; McMurray \& Hackney, 2005). This is also confirmed by low values of lipid oxidation in DS group and may be related to lower $\mathrm{VO}_{2 \max }$ for these subjects, and by free fatty acids values that remain high, suggesting that peripheral utilisation of lipids is insufficient when intensity and duration of the effort increases.

Compared with controls, hormonal responses to exercise in young adults with trisomy 21 were thus attenuated, which could explain cardiovascular and metabolic limitation of these subjects to continue muscular exercise (Bricout et al., 2008; Flore et al., 2008). The aim of these two studies was to analyse if hormonal responses could explain an exercise limitation in DS, and if it exist an oxidative stress in this population. DS is a risk factor for metabolic syndrome and cardiovascular disease. The greater oxidative stress described in DS can increase this risk owing to its potential deleterious effects on insulin sensitivity. We hypothesised that metabolic syndrome or its markers, at rest and during exercise, are more pronounced in young adults with DS.

Fourteen young men with DS (mean age $22.5 \pm 0.7$ years) took part to the study. During a treadmill sub-maximal incremental test, blood samples were collected for determination of hormonal and metabolic variables.

Compared to controls, DS individuals showed lower $\mathrm{VO}_{2 \max }(60.8 \pm 2.4$ versus $44.4 \pm 3.3$ $\mathrm{ml} \cdot \mathrm{min}^{-1} \cdot \mathrm{kg}^{-1}$ respectively; $\left.\mathrm{P}<0.05\right)$ but it was close to the predicted value $(95 \pm 6 \%)$. They presented a lower duration of sub-maximal incremental exercise $(\mathrm{P}<0.001)$.

At rest, DS individuals showed greater catecholamine, insulin and leptin values $(\mathrm{P}<0.05)$, but lower testosteronemia and cortisolemia $(\mathrm{P}<0.05)$ compared to controls. During submaximal incremental tests, catecholamine and cortisol did not increased, whereas the insulin concentration of DS individuals was significantly higher $(\mathrm{P}<0.01)$ compared to controls. Glycaemia increased significantly at the end of sub-maximal incremental test for controls but not for DS individuals $(\mathrm{P}<0.01)$. In DS participants, as expected, oxidative stress was greater than in controls $(+15 \%$; $<<0.001)$ at rest and throughout the exercise protocol. Although a greater fat mass (DS: $19.9 \pm 1.3 \%$; controls: $13.5 \pm 0.9 \%$; $<<0.001$ ), and a lower insulin sensitivity (HOMA-IR DS: $1.09 \pm 0.16$; HOMA controls: $0.64 \pm 0.13$; $\mathrm{P}<0.05$ ) was observed for DS participants, a metabolic syndrome could not be shown. Maximal fatoxidation rate was lower in DS participants (DS $=394.2 \pm 69.9$ versus controls $=486.1 \pm 134.8$ mg. min $\left.^{-1} ; \mathrm{P}<0.01\right)$ but it was in the normal range. 
These endocrine and metabolic profiles at rest and during exercise may limit endurance performance in DS individuals.

So now, the aim of our research team is to assess chronotropic adaptation to exercise in non obese young physically active adult males with DS and its relationships with exercise tolerance and catecholamine response. In a preliminary study, fourteen DS and healthy agematched controls initially performed a graded maximal exercise test. Chronotropic incompetence $(\mathrm{CI})$ was characterised if less than $80 \%$ of the chronotropic reserve was achieved.

Only four DS subjects (28\%) had CI whereas none in controls. DS with CI showed exercise intolerance with HR peak and peak oxygen uptake lower than those without CI. Conversely, DS with CI had impaired epinephrine and norepinephrine responses to exercise. The association between $\mathrm{CI}$, exercise intolerance and impaired catecholamine response in a subgroup of DS, indicate that biological effects of catecholamine are necessary for optimising acute exercise adaptations. Nevertheless, the results suggest that reduced chronotropic response and aerobic power in DS without CI are likely to be due to the metabolic consequences of fat mass excess and inherited oxidative stress rather than to impaired catecholamine drive.

However, the results of that work are still being acquired and it will be necessary to obtain results on a more important number of subjects to confirm our current results.

\section{Interest of the promotion and guidance of an active lifestyle in populations with specific needs such as Down Syndrome}

\section{Direct assessment of health}

There is no pharmacological treatment for trisomy 21. Nevertheless, the knowledge of physiological and biological parameters of trisomy 21 by means of studies based on protocols of effort is an original path that could bring: (1) load response adapted to the daily lives of subjects with trisomy 21, (2) results directly applicable to the health of these subjects (treatment of endocrine diseases, nutritional advice, and rehabilitation training ...).

By promoting a physically active life, as it has been shown in various reports across the Atlantic (A Report of the Surgeon General. U.S. Department of Health \& Human Services, 1996) a reduction in health costs is logically expected for all categories of "persons with special needs", usually victims of the adverse effects of inactivity. The qualitative accompanying aging people with disabilities, is an important goal for our wealthy societies. The basic criteria for this support which actually extends from childhood to old age, is provided by professionals who educate, guide and look after these populations. These professionals should benefit from the results of this completed investigation on the effects of physical activity. Indeed, while renewing their knowledge and professional practices, they should be able to provide better care, better quality of life and even better end of life for all the elderly, disabled or not.

In addition, regular physical activity is widely recognised as a means of improving the health and the quality of life of people with disabilities. These benefits have already been demonstrated, at least temporarily. Over the last decade, the advanced educational media have helped give these people a more active lifestyle that has immediately impacted on their recognition and social integration. But as physical exercise is considered as a stress, questions remain as to the metabolic and hormonal adaptations of these DS subjects. 
Similarly, long-term benefits of an active lifestyle, with a perspective of delaying the ageing of the person to maintain a certain level of mental and physical well-being, must be better identified.

Propositions could be considered, and should aim at finding the best conditions (nature, intensity, frequency) of an intervention based on physical activity among this specific population. It seems likely that the physical training of people with trisomy 21 should be scheduled, monitored and controlled in order to derive benefits for their health and quality of life.

In this context, Rimmer et al., (2004) have shown that a combined resistance and aerobic training program can improve physical fitness in this population; however, it remains unclear whether this transfers to improved performance on functional tasks of daily living.

Persons with DS have also reduced muscle strength and muscular endurance compared with their peers without disability and also compared with their peers with an intellectual disability but without DS (Croce \& Horvat, 1992). Muscle weakness can also impact the ability of DS subjects to perform everyday activities, such as walking, maintaining balance while standing, and achieving all the movements of daily life. Further, because their workplace activities typically emphasize physical rather than cognitive skills, decreased strength can negatively impact the vocational and social development of adults with DS in the workforce. It has been shown that resistance training can improve work productivity in individuals with intellectual disability (Croce \& Horvat, 1992). It might be expected that adults with DS have difficulty taking part in or being motivated to continue with a progressive resistance exercise program. Compliance with a training program can be very variable depending on the intellectual disabilities. To obtain a positive impact, it is necessary that the training program appeared to be a safe intervention for people with DS. No major adverse events should be reported by the participants, their families, or the fitness trainers involved in the program, during or after the training sessions.

To support the opinion that the activity is required in DS population, Heyne et al. (1997) have shown that the absence of a meaningful leisure program will foster maladaptive or aggressive behaviours. These authors point out the significance of leisure programs but also the importance of physical activities which will expand the social network, promote friendships and, introduce a sense of autonomy. Songster et al. (1997) reinforce this argument and emphasise that consistent training and sports competition in Special Olympics are essential to the physical, mental and social developments of young person with Down syndrome.

\section{Conclusion}

Children and young adults with Down syndrome have the opportunities to learn the different aspects of physical education and thus the means to become a physically educated person. They are capable of learning sports techniques, can progress, and participate in sports competition.

Nevertheless, physical activities need to be carefully taught and chosen for their fitness benefit. It is necessary to encourage enough recreational activities to maintain a sufficient motivation, so physical educational programs for this specific population should include all activities to learn, to understand both kinaesthetically and cognitively movements and abilities. Finally, the physical activity becomes enjoyable, social, repeatable, valued for its own sake, and we contribute to the formation of autonomous adults, physically active and educated. 


\begin{tabular}{|c|c|c|c|c|c|c|}
\hline \multicolumn{2}{|c|}{ CARDIOVASCULARA DATA } & \multirow{2}{*}{$\begin{array}{l}\text { age } \\
\text { years }\end{array}$} & \multirow{2}{*}{$\begin{array}{l}\text { FC rest } \\
\text { bpm }\end{array}$} & \multirow{2}{*}{$\begin{array}{l}\text { FC peak } \\
\text { bpm }\end{array}$} & \multirow{2}{*}{$\begin{array}{l}\text { VO2 peak } \\
\mathrm{ml} / \mathrm{min} / \mathrm{kg}\end{array}$} & \multirow{2}{*}{$\begin{array}{l}\text { SBP } \\
\mathrm{mmHg}\end{array}$} \\
\hline Authors & Review & & & & & \\
\hline Baynard et al., (2004) & Arch. Phys. Med Rehabil. & $20,8+/-0,9$ & $71+/-3,4$ & $161+/-5,3$ & $27,4+/-1,8$ & nd \\
\hline Baynard et al., (2008) & M.S.S.E & $25+/-2$ & nd & $167+/-$ nd & $24+/-$ nd & nd \\
\hline Bricout et al., (2008) & J. NeuroEndocrinol. & $22,5+/-0,7$ & $57,7+/-3,7$ & $180+/-2$ & $44,2+/-3,04$ & $116,0+/-2,8$ \\
\hline Draheim et al., (2002) & Mental Retard. & $34,5+/-10,0$ & nd & nd & nd & $111,4+/-13,6$ \\
\hline Eberhard et al., (1989) & J. Ment. Defic. Res. & $14,8+/-2,2$ & $67,1+/-12,6$ & $123,6+/-19,7$ & $47,6+/-8,1$ & $107+/-14,6$ \\
\hline Eberhard et al., (1997) & Adapt. Phys. Activ. Quater. & $17,5+/-1,7$ & nd & $162,2+/-\quad 18,9$ & $48+/-1$ & nd \\
\hline Fernhall et al., (1996) & M.S.S.E & $26,7+/-5,9$ & nd & $164+/-14,4$ & $27,6+/-6,4$ & nd \\
\hline Fernhall et al., (2003) & J.A.P & $23,8+/-1,8$ & $66,4+/-4,6$ & $154,+/-4,2$ & $18,1+/-1,6$ & $112,2+/-6,6$ \\
\hline Fernhall et al., (2005) & Arch. Phys. Med Rehabil. & $25,1+/-7,3$ & 72,5 & $159+/-16,8$ & $19,7+/-6,4$ & $117,5+/-$ nd \\
\hline Fernhall et al., (2009) & Am. J Cardiol. & $24+/-7$ & nd & $170+/-10$ & $27,3+/-5,6$ & nd \\
\hline Figueroa et al., (2005) & Clin. Auton. Res. & $27,8+/-8,1$ & $76+/-3$ & nd & nd & $115+/-4$ \\
\hline Guerra et al., (2003) & Arch. Phys. Med Rehabil. & $24,3+/-3,5$ & $69,0+/-11,2$ & $165,0+/-14,7$ & $31,9+/-6,6$ & nd \\
\hline Gouloupoulou et al. (2006) & Am. J. Ment. Retard. & $24+/-0,9$ & $70+/-1,5$ & $162+/-2,4$ & $24,5++/-1,0$ & nd \\
\hline Hefferman et al., (2005) & M.S.S.E & $25+/-2,4$ & $72+/-$ nd & nd & nd & $106,1+/-2,9$ \\
\hline Iellamo et al., (2005) & Am. J. Physiol. & $26,3+/-2,3$ & nd & nd & nd & $116,1+/-2,7$ \\
\hline Mendonca et al., (2011) & Arch. Phys. Med Rehabil. & $36,5+/-5,5$ & $69,6+/-12,2$ & $167,6+/-19,1$ & $31,7+/-7,9$ & nd \\
\hline Mendonca et al., (2011) & Res. Dev. Disabilities & $34,9+/-1,1$ & $71+/-$ nd & $171,5+/-4,9$ & $30,4+/-2,1$ & nd \\
\hline Millar et al., ( 1993) & M.S.S.E & $18,4+/-2,9$ & nd & $172,8+/-15,1$ & $26,95+/-7,92$ & nd \\
\hline Rimmer et al., (2004) & Am. J. Ment. Retard. & $40,6+/-6,5$ & nd & $133+/-21$ & $14,7+/-4,5$ & nd \\
\hline Tsimaras et al., (2003) & Percept. Motor Skills & $24,7+/-2,7$ & nd & $181,0+/-3,8$ & $30,5+/-4,3$ & nd \\
\hline
\end{tabular}

nd : not determined, SBP : systolic blood pressure.

Table 1. Cardiovascular data.

\begin{tabular}{llllll}
\hline \multirow{2}{*}{ Authors } & $\begin{array}{c}\text { A.N.S DATA } \\
\text { Review }\end{array}$ & age (years) & \multicolumn{1}{c}{ LF } & \multicolumn{1}{c}{ HF } & \multicolumn{1}{c}{ LF/HF } \\
\hline Baynard et al., (2004) & Arch. Phys. Med Rehabil. & $20,8+/-0,9$ & $1264,1+/-226,2 \mathrm{~ms}^{2}$ & $1418,1+/-268,6 \mathrm{~ms}^{2}$ & $1,81+/-0,42$ \\
Figueroa et al., (2005) & Clin. Auton. Res. & $27,8+/-8,1$ & $5,4+/-0,2 \ln . \mathrm{ms}^{2}$ & $6,3+/-0,2 \ln \cdot \mathrm{ms}^{2}$ & $1,18+/-0,06$ \\
Iellamo et al., (2005) & Am. J. Physiol. & $26,3+/-2,3$ & $51,3(35,5$ to 59,4$)$ n.u & $34,6(27,4$ to 49,9$)$ n.u & nd \\
Gouloupoulou et al. (2006) & Am. J. Ment. Retard. & $24+/-0,9$ & $6,93+/-0,12$ ln.ms & $6,57+/-0,16 \ln . \mathrm{ms}^{2}$ & $0,35+/-0,11 \mathrm{ln} \cdot \mathrm{ms}^{2}$ \\
Mendonca et al., (2011) & Res. Dev. Disabilities & $34,9+/-1,1$ & $6,8 \ln \mathrm{ms}^{2}$ & $5,8 \ln \mathrm{ms}^{2}$ & 1,1 \\
\hline
\end{tabular}

LF: low frequency power expressed in $\mathrm{ms}^{2}$ or $\ln \mathrm{ms}^{2}$ or n.u (normalised units)

HF: high frequency power; LF/HF ratio reflected the Autonomic Nervous System balance (sympathetic/parasympathetic).

Table 2. Autonomic Nervous System Data.

\begin{tabular}{|c|c|c|c|c|c|c|}
\hline $\begin{array}{l}\text { ENDOCRINE DATA } \\
\text { Authors }\end{array}$ & Review & age (years) & Testosterone & TSH & T3 & T4 \\
\hline Sakadamis et al., (2002) & Eur. J. Obstetr. Gynecol & $26.4+/-3.9$ & $31.26+/-14.1 \mathrm{nmol} / \mathrm{L}$ & $\overline{\text { nd }}$ & $\overline{\text { nd }}$ & nd \\
\hline Suzuki et al., (2010) & Int. J. Urol. & $28(15-54)$ & $3.68+/-1.34 \mathrm{ng} / \mathrm{mL}$ & nd & nd & nd \\
\hline Bricout et al., (2008) & J. NeuroEndocrinol. & $22.5+/-0.7$ & $15.45+/-1.63 \mathrm{nmol} / \mathrm{L}$ & $6.33+/-0.93 \mathrm{mUI} / \mathrm{L}$ & $4.35+/-0.11 \mathrm{pmol} / \mathrm{L}$ & $16.22+/-0.60 \mathrm{pmol} / \mathrm{L}$ \\
\hline Oliveira et al., (2002) & J. Pediatr (Rio J) & $3.4+/-1.8$ & nd & $7.2 \pm 4.2 \mu \mathrm{U} / \mathrm{mL}$ & $9.8 \pm 2.1 \mathrm{ng} / \mathrm{dL}$ & $1.7 \pm 0.4 \mathrm{ng} / \mathrm{dL}$ \\
\hline Murdoch et al., (1977) & J. Clin. Endocrinol. Metab & adults & nd & $7.6+/-10.7 \mathrm{mU} / \mathrm{L}$ & $1.61+/-0.47 \mathrm{nmol} / \mathrm{L}$ & $69.1+/-22.2 \mathrm{nmol} / \mathrm{L}$ \\
\hline Konings et al., (2001) & Eur. J. Endocrinol. & 1.5 to 13 & nd & $6.5+/-1.3 \mathrm{mU} / \mathrm{L}$ & & 14.3 to $18.5 \mathrm{pmol} / \mathrm{L}$ \\
\hline
\end{tabular}

TSH: thyroid stimulating hormone; T3: tri-iodothyronine; T4: thyroxine; nd : not determined,

Table 3. Endocrine data. 


\begin{tabular}{|c|c|c|c|c|c|c|c|}
\hline $\begin{array}{l}\text { ENDOCRINE DATA } \\
\text { Authors }\end{array}$ & Review & $\begin{array}{l}\text { age } \\
\text { years }\end{array}$ & $\begin{array}{l}\text { cortisol (rest) } \\
\mathrm{nmol} / \mathrm{L}\end{array}$ & $\begin{array}{l}\text { Epinephrine } \\
\text { rest (pmol } / \mathrm{mL} \text { ) }\end{array}$ & $\begin{array}{l}\text { NorEpinephrine } \\
\text { rest (pmol/mL) }\end{array}$ & $\begin{array}{l}\text { Epinephrine } \\
\text { post ex (pmol/mL) }\end{array}$ & $\begin{array}{l}\text { NorEpinephrine } \\
\text { post ex (pmol/mL) }\end{array}$ \\
\hline Murdoch et al., (1979) & J. Ment. Defic. Res. & $39(22-57)$ & $476.6+/-\mathrm{nd}$ & & & & \\
\hline Bricout et al., (2008) & J. NeuroEndocrinol. & $22.5+/-0.7$ & $365.1+/-14.7$ & $0.67+/-0.14$ & $3.62+/-0.53$ & $1.19+/-0.22$ & $10.21+/-2.64$ \\
\hline Eberhard et al., (1991) & J. Ment. Defic. Res. & $17.5+/-1.7$ & nd & $0.38+/-0.23$ & $1.08+/-0.78$ & $0.92+/-0.41$ & $6.32+/-3.41$ \\
\hline Eberhard et al., (1997) & Adapt. Phys. Activ. Quater. & Boys: $18+/-1.7$ & nd & $0.45+/-0.3$ & $1.3+/-0.9$ & $1+/-0.45$ & $6.4+/-4.4$ \\
\hline Eberhard et al., (1997) & Adapt. Phys. Activ. Quater. & Girls: $16.7+/-1.5$ & nd & $0.4+/-0.3$ & $0.63+/-0.25$ & $0.78+/-0.3$ & $6.9+/-1.6$ \\
\hline
\end{tabular}

TSH: thyroid stimulating hormone; T3: tri-iodothyronine; T4: thyroxine; nd : not determined,

Table 4. Endocrine data.

\section{References}

Baynard, T.; Pitetti, KH.; Guerra, M. \& Fernhall, B. (2004). Heart rate variability at rest and during exercise in persons with Down syndrome. Archives of Physical Medicine and Rehabilitation. Vol.85, n.8, pp. 1285-1290.

Baynard, T.; Pitetti, KH.; Guerra, M.; Unnithan, VB \& Fernhall, B. (2008). Age-related changes in aerobic capacity in individuals with mental retardation: A 20-yr review. Medicine E Science in Sports \& Exercise. Vol.40, N.11, pp. 1984-1989.

Beange, H.; Mc Elduff, A. \& Baker, W. (1995). Medical disorders of adults with mental retardation: a population study. American Journal of Mental Retardation. Vol.99, pp. 595-604.

Bell, NJ.; Kozar, W. \& Martin, AW. (1977). The impact of Special Olympics on participants, parents and the community. Lubbock, TX Technical University.

Bjorntrop, P. \& Rosmond, R. (2000). Neuroendocrine abnormalities in visceral obesity. International Journal of Obesity and related metabolic disorders. Vol.24, pp. S80-S85.

Bricout, V-A.; Guinot, M.; Faure, P.; Flore, P.; Eberharrd, Y.; Garnier, P. \& Favre-Juvin, A. (2008). Are hormonal responses to exercise in young men with Down's Syndrome related to reduced endurance performance? Journal of Neuroendocrinology. Vol.20, pp. 558-565.

Colbert, LH.; Visser, M. \& Simonsick, EM. (2004). Physical activity, exercise and inflammatory markers in older adults: findings from the Health, Aging and Body composition Study. Journal of American Geriatrics Society. Vol.52, pp. 10981104.

Croce, RV. \& Horvat, M. (1992). Effects of reinforcement based exercise on fitness and work productivity in adults with mental retardation. Adapted Physical Activity Quaterly. Vol.9, pp. 148-178.

Day, SM.; Strauss, DJ.; Shavelle, RM. \& Reynolds, RJ. Mortality and causes of death in persons with Down syndrome in California. (2005). Developmental Medicine and Child Neurology. Vol.47, pp. 171-176.

Draheim, CC.; Williams, DP. \& Mc Cubbin, JA. (2002). Prevalence of physical inactivity and recommended physical activity in community-based adults with mental retardation. Mental Retardation. Vol.40, n.6, pp. 436-444.

Eberhard, Y.; Eterradossi, J. \& Rappachi, B. (1989). Physical aptitudes to exertion in children with Down's syndrome. Journal of Mental Deficiency Research. Vol.33, pp. 167-174.

Eberhard, Y.; Eterradossi, J. \& Therminarias, A. (1991). Biochemical changes and catecholamine responses in Down's syndrome adolescents in relation to 
incremental maximal exercise. Journal of Mental Deficiency Research. Vol.35, n². pp. 140-146.

Eberhard, Y.; Eterradossi, J.; Foulon, T. \& Groslambert, P. (1993). Variations des lipoprotéines plasmatiques chez les adolescents trisomiques 21 en réponse à un test d'endurance physique. Pathologie \& Biologie. Vol.41, n.5, pp. 482-486.

Eberhard, Y.; Eterradossi, J.; Foulon, T. \& Groslambert, P. (1996). Influence conjuguée de conseils alimentaires et de l'activité physique d'endurance sur les lipoprotéines plasmatiques chez les adolescents trisomiques 21. Sciences $\mathcal{E}$ Sports. Vol.11, pp. 145151.

Eberhard, Y.; Eterradossi, J. \& Debû, B. (1997). Biological Changes induced by Physical Activity in Individuals with Down's Syndrome. Adapted Physical Activity Quaterly. Vol.14, pp. 166-175.

Eberhard, Y. (2006). A better living and a better ageing thanks to sport for persons with intellectual deficits. Sciences \& Sports. Vol.21, pp. 236-242.

Fernhall, B.; Pitetti, KH.; Rimmer, JH.; Mc Cubbin, JA.; Rintala, P.; Millar, AL.; Kittredge, J. \& Burkett, LN. (1996). Cardiorespiratory capacity of individuals with mental retardation including Down syndrome. Medicine $\mathcal{E}$ Science in Sports E Exercise. Vol.28, n.3, pp. 366-371.

Fernhall, B.; McCubbin, JA.; Pitetti, KH.; Rintala, P.; Rimmer, JH.; Millar, AL. \& De Silva, A. (2001). Prediction of maximal heart rate in individuals with mental retardation. Medicine Sciences \& Sports Exercise. Vol.33, n.10, pp. 1655-1660.

Fernhall, B. \& Otterstetter, M. (2003). Attenuated responses to sympathoexcitation in individuals with Down syndrome. Journal of Applied Physiology. Vol.94, n.6, pp. 2158-2165.

Fernhall, B.; Figueroa, A.; Collier, S.; Baynard, T.; Giannopoulou, I.; Gouloupoulou, S. (2005). Blunted Heart Rate Response to Upright Tilt in People With Down Syndrome. Archives of Physical Medicine and Rehabilitation. Vol.86, pp. 813-818.

Fernhall, B.; Baynard, T.; Collier, SR.; Figueroa, A.; Gouloupoulou, S.; Kamimori, GH. \& Pitetti, KH. (2009). Catecholamine response to maximal exercise in persons with Down syndrome. American Journal of Cardiology. Vol. 103, pp. 724-726.

Figueroa, A.; Collier, S.; Baynard, T.; Giannopoulou, I.; Gouloupoulou, S. \& Fernhall, B. (2005). Impaired vagal modulation of heart rate in individuals with Down syndrome. Clinical Autonomic Research. Vol.15, n.1, pp. 45-50.

Finesilver, C. (2002). A new age for childhood diseases: Down syndrome. RN. Vol.65, pp. 43-48.

Flore, P.; Bricout, V-A.; Van Biesen, D.; Guinot, M.; Laporte, F.; Pépin, J-L.; Eberhard, Y.; Favre-Juvin, A. \& Faure, P. (2008). Oxidative stress and metabolism at rest and during exercise in persons with Down Syndrome. European Journal of Cardiovascular Prevention \& Rehabilitation. Vol. 15, N.1, pp. 35-42.

Furlan, R.; Pagani. \& M, Malliani, A. (1993). Effects of exercise and training on control of heart rate. Cardiovascular Research. Vol.27, pp. 2286-2287.

Galbo, H. (1985). The hormonal response to exercise. Proceedings of the Nutrition Society. Vol. 44 , pp. 257-266. 
Gouloupoulou, S.; Baynard, T.; Collier, S.; Giannopoulou, I.; Figueroa, A.; Beets, M.; Pitetti, K. \& Fernhall, B. (2006). Cardiac autonomic control in individuals with Down syndrome. American Journal of Mental Retardation. Vol.111, n.1, pp. 27-34.

Grote, L.; Hedner, J. \& Peter, JH. (2004). The heart rate response to exercise is blunted in patients with sleep-related breathing disorder. Cardiology. Vol.102, n.2, pp. 93-99.

Grundy, S.; Bazzarre, T. \& Cleeman, J. (2000). Prevention conference V. Beyond secondary prevention: identifying the high risk patient for primary prevention, medical office assessment. Circulation. Vol.101, pp. e3-e11.

Guerra, M.; Llorens, N. \& Fernhall, B. (2003). Chronotropic incompetence in persons with Down Syndrome. Archives of Physical Medicine and Rehabilitation. Vol.84, pp. 16041608.

Horvat, M. \& Croce, R. (1995). Physical rehabilitation of individuals with mental retardation: physical fitness and information processing. Critical Reviews in Physical and Rehabilitation Medicine. Vol. 7, pp. 233-252.

Hefferman, KS.; Baynard, T.; Gouloupoulou, S.; Giannopoulou, I.; Collier, SR.; Figueroa, A. \& Fernhall B. (2005). Baroreflex sensitivity during static exercise in individuals with Down syndrome. Medicine $\mathcal{E}$ Science in Sports E Exercise. Vol.37, $\mathrm{n}^{\circ} .12$, pp. 20262031.

Heyne, LA.; Schleien, SJ. \& Rynders, JE. (1997). Promoting quality of life through recreation participation. In Pueschel, SM. \& Sustrova, M. (Eds.). Adolescents with Down Syndrome. pp. 317-340. Baltimore: Paul H Brookes Publishing Co.

Iellamo, F.; Galante, A.; Legarante, JM.; Lipp, ME.; Condoluci, C.; Albertini, G. \& Volterrani, M. (2005). Altered autonomic cardiac regulation in individuals with Down syndrome. American Journal of Physiology - Heart and Circulatory Physiology. Vol.289, $\mathrm{n}^{\circ} .6, \mathrm{pp} . \mathrm{H} 2387-2391$.

Konings, CH.; Van Trotsenburg, AS.; Ris-Stalpers, C.; Vulsma, T.; Wiedijk, BM. \& De Vijlder, JJ. (2001). Plasma thyrotropin bioactivity in Down's syndrome children with subclinical hypothyroidism. European Journal of Endocrinology. Vol.144, pp. $1-4$

Lauer, MS.; Okin, PM.; Larson, MG.; Evans, JC. \& Levy, D. (1996). Impaired heart rate response to graded exercise. Prognostic implications of chronotropic incompetence in the Framingham Heart Study. Circulation. Vol.93, pp. 1520-1526.

Lauer, MS. (2004). Chronotropic incompetence: ready for prime time. The Journal of American College of Cardiology. Vol.44, pp. 431-432.

Lohse, MJ. (1996). Mechanisms of the regulation of adrenergic beta-receptors. Zeitschrift für kardiologie. Vol.85, n.7S, pp. 1-3.

Mann, DM.; Yates, PO.; Marcyniuk, B. \& Ravindra CR. (1985). Pathological evidence for neurotransmitter deficits in Down's syndrome of middle age. Journal of Mental Deficiency Research. Vol.29, pp. 125-135.

Marliss, EB. \& Vranic, M. (2002). Intense exercise as a unique effect on both insulin release and its role in glucoregulation: implications for diabetes. Diabetes. Vol.51, $\mathrm{n}^{\circ} .1, \mathrm{pp}$. S271-283.

McMurray, RG. \& Hackney, AC. (2005). Interactions of metabolic hormones, adipose tissue and exercise. Sports Medicine. Vol.35, pp. 393-412. 
McGavock, JM.; Eves, ND.; Mandic, S.; Glenn, NM.; Quinney, HA. \& Haykowsky, MJ. (2004). The role of exercise in the treatment of cardiovascular disease associated with type 2 diabetes mellitus. Sports Medicine. Vol.34, n.1, pp. 27-48.

Monroe, M.; Van Pelt, R.; Schiller, B.; Seals, D. \& Jones, P. (2000). Relation of leptin and insulin to adiposity-associated elevations in sympathtic activity with age in humans. International Journal of Obesity. Vol.24, pp. 1183-1187.

Mendonca, GV.; Pereira, FD. \& Fernhall, B. (2011). Cardiac autonomic function during submaximal treadmill exercise in adults with Down syndrome. Research in Developmental Disabilities. Vol.32, pp. 532-539.

Mendonca, GV.; Pereira, FD. \& Fernhall, B. (2011). Effects of combined aerobic and resistance exercise training in adults with and without Down syndrome. Archives of Physical Medicine and Rehabilitation. Vol. 92, pp. 37-45.

Millar, A.; Fernhall, B. \& Burkett L. (1993). Effects of aerobic training in adolescents with Down syndrome. Medicine \& Science in Sports \& Exercise. Vol. 5, pp. 270-274.

Montgomery, D.; Reid, G. \& Seidl, C. (1988). The effects of two physical fitness programs designed for mentally retarded adults. Canadian Journal of Sports Sciences. Vol.13, pp. 73-78.

Murray, J. \& Ryan-Krause, P. (2010). Obesity in children with Down syndrome: background and recommendations for management. Pediatric Nursing. Vol. 36, $n^{\circ} .6, p p$. 314319.

Murdoch, JC. (1977). Thyroid function in adults with Down's syndrome. Journal of Clinical Endocrinology \& Metabolism. Vol.44, n.3, pp. 453-458.

Murdoch, JC.; Gray, CA.; McCarty, DG. \& Ratcliffe, JG. (1978). Pituitary function in Down's syndrome. Journal of Mental Deficiency Research. Vol.22, n.4, pp. 273-275.

Murdoch, JC.; Giles, CA.; Grant, JK. \& Ratcliffe, JG. (1979). Hypothalamic-pituitaryadrenocortical function in adults Down's syndrome. Journal of Mental Deficiency Research. Vol.23, pp. 157-162.

Nagaoka, H.; Sachio, S.; Lizuka, T.; Imai, S. \& Nagai R. (1996). Relation between depressed cardiac response to exercise and autonomic nervous activity in mildly symptomatic patients with idiopathic dilated cardiomyopathy. Chest. Vol.109, $\mathrm{n}^{\circ} .4$, pp. 925-932.

Oberbach, A.; Tonjes, A.; Kloting, N.; Fasshauer, M.; Kratzsch J. \& Busse, MW. (2006). Effect of 4 week physical training program on plasma concentrations of inflammatory markers in patients with abnormal glucose tolerance. European Journal of Endocrinology.Vol.154, pp. 577-585.

Oliveira, ATA.; Longui, CA.; Calliari, LEP.; Ferone, EA.; Kawaguti, FS. \& Monte, O. (2002). Evaluation of the hypothalamic-pituitary-thyroid axis in children with Down syndrome. Jornal de Pediatria. (Rio J). Vol.8, n.4, pp. 295-300.

Pitetti, K.; Jackson, J.; Stubbs, B.; Campbell, K. \& Battar, S. (1989). Fitness levels of adult Special Olympics participants. Adapted Physical Activity Quaterly. Vol.6, pp. 354-370.

Pitetti, K. \& Tan, DM. (1991a). Effects of a minimally supervised exercise program for mentally retarded adults. Medicine Sciences \& Sports Exercise. Vol.23, n.5, pp. 594601. 
Pitetti, KH. \& Campbell, KD. (1991b). Mentally retarded individuals: a population at risk? Medicine Sciences \& Sports Exercise. Vol;23, n.5, pp. 586-593.

Pitetti, K.; Rimmer, J. \& Fernhall, B. (1993). Physical fitness and adults with mental retardation. An overview of current research and future directions. Sports Medicine. Vol.16, $n^{\circ} .1$, pp. 23-56.

Prasher, VP. \& Krishnan, VHR. (1993). Age of onset and duration of dementia in people with Down syndrome. A study of 98 reported cases. International Journal of Geriatric Psychiatry. Vol. 8, pp. 915-922.

Rimmer, JH.; Heller, T.; Wang, E. \& Valerio, I. (2004). Improvements in physical fitness in adults with Down syndrome. American Journal of Mental Retardation. Vol.109, n.2, pp. 165-174.

Sakadamis, A.; Angelopoulou, N.; Matziarib, C.; Papameletiouc, V. \& Souftas V. (2002) Bone mass, gonadal function and biochemical assessment in young men with trisomy 21. European Journal of Obstetrics \& Gynecology and Reproductive Biology. Vol.100, pp. 208-212.

Sasagawa, I.; Nakada, T.; Hashimoto, T.; Ishigooka, M.; Izumiya, K.; Kubota, H. \& Tomaru, M. (1993). Hormone profiles and contralateral testicular histology in Down's syndrome with unilateral testicular tumor. Archives of Andrology.Vol.30, pp. 93-98.

Sharav, T.; Landau, H.; Zadik, Z. \& Einarson, TR. (1991). Age-related patterns of thyroid-stimulating hormone response to thyrotropin-releasing hormone stimulation in Down syndrome. American Journal of Diseases of Children. Vol.145, pp. 172-175.

Songster, TH.; Smith, G.; Evans, M.; Munson, D. \& Behen, D. (1997). Special Olympics and athletes with Down syndrome. In Pueschel, SM. \& Sustrova, M. (Eds.). Adolescents with Down Syndrome. pp. 341-357. Baltimore: Paul H Brookes Publishing Co.

Sutherland, G.; Couch, M. \& Iacono, T. (2002). Health issues for adults with developmental disability. Research in Developmental Disabilities. Vol.23, pp. 422-445.

Suzuki, K.; Nakajima, K.; Kamimura, S.; Takasugi, K.; Suzuki, Y.; Sekine, H. \& Ishii, N. (2010). Eight case reports on sex-hormone profiles in sexually mature male Down syndrome. International Journal of Urology. Vol.17, pp. 1008-1010.

Task force of the European society of cardiology and the North American society of pacing and electrophysiology. Heart rate variability: guidelines. (1996). European Heart Journal. Vol.17, pp. 354-381.

Thompson, SB. (1999). Examining dementia in Down syndrome (DS): decline in social abilities in DS compared to other learning disabilities. Topics in Clinical Gerontology. Vol.20, pp. 3-44.

Tsimaras, V.; Giagazoglou, P. \& Fotiadou, E. (2003). Jog-walk training in cardio-respiratory fitness of adults with Down syndrome. Perceptual and Motor Skills. Vol.96, pp. 1239-1251.

Wellen, KE. \& Hotamisligil, GS. (2005). Inflammation, stress, and diabetes. Journal of Clinical Investigation. Vol.115, n.5, pp. 1111-1119

Wilkoff, BL. \& Miller, RE. (1992). Exercise testing for chronotropic assessment. Cardiology Clinics. Vol.10, pp. 705-717. 
Wisniewski, KE. (1990). Down's syndrome children often have brain with maturation delay, retardation of growth, and cortical dysgenesis. American Journal of Medical Genetics. Vol. 7 suppl, pp. 274-290.

Yates, CM.; Simpson, J.; Maloney, AFJ.; Gordon, A. and Reid, AH. (1980). Alzheimer-like cholinergic deficiency in Down's syndrome. Lancet. Vol.2, pp. 979. 




\author{
Genetics and Etiology of Down Syndrome \\ Edited by Prof. Subrata Dey
}

ISBN 978-953-307-631-7

Hard cover, 328 pages

Publisher InTech

Published online 29, August, 2011

Published in print edition August, 2011

This book provides a concise yet comprehensive source of current information on Down syndrome. Research workers, scientists, medical graduates and paediatricians will find it an excellent source for reference and review. This book has been divided into four sections, beginning with the Genetics and Etiology and ending with Prenatal Diagnosis and Screening. Inside, you will find state-of-the-art information on: 1. Genetics and Etiology 2. Down syndrome Model 3. Neurologic, Urologic, Dental \& Allergic disorders 4. Prenatal Diagnosis and Screening Whilst aimed primarily at research workers on Down syndrome, we hope that the appeal of this book will extend beyond the narrow confines of academic interest and be of interest to a wider audience, especially parents and relatives of Down syndrome patients.

\title{
How to reference
}

In order to correctly reference this scholarly work, feel free to copy and paste the following:

Véronique Aurélie Bricout (2011). Endocrine and Autonomic Nervous Adaptations during Physical Exercise in Down Syndrome, Genetics and Etiology of Down Syndrome, Prof. Subrata Dey (Ed.), ISBN: 978-953-307-6317, InTech, Available from: http://www.intechopen.com/books/genetics-and-etiology-of-downsyndrome/endocrine-and-autonomic-nervous-adaptations-during-physical-exercise-in-down-syndrome

\section{INTECH}

open science | open minds

\section{InTech Europe}

University Campus STeP Ri

Slavka Krautzeka 83/A

51000 Rijeka, Croatia

Phone: +385 (51) 770447

Fax: +385 (51) 686166

www.intechopen.com

\section{InTech China}

Unit 405, Office Block, Hotel Equatorial Shanghai

No.65, Yan An Road (West), Shanghai, 200040, China 中国上海市延安西路65号上海国际贵都大饭店办公楼 405 单元

Phone: +86-21-62489820

Fax: $+86-21-62489821$ 
(C) 2011 The Author(s). Licensee IntechOpen. This chapter is distributed under the terms of the Creative Commons Attribution-NonCommercialShareAlike-3.0 License, which permits use, distribution and reproduction for non-commercial purposes, provided the original is properly cited and derivative works building on this content are distributed under the same license. 